\title{
Trophic categorization in the Rías Baixas (NW Spain): nutrients in water and in macroalgae*
}

\author{
RUBÉN VILLARES ${ }^{1}$ and ALEJO CARBALLEIRA ${ }^{2}$ \\ ${ }^{1}$ Ecología, Escuela Politécnica Superior, Universidad de Santiago de Compostela, 27002 Lugo, Spain. \\ E-mail: bfrubenv@usc.es \\ ${ }^{2}$ Ecología, Facultad de Biología, Universidad de Santiago de Compostela, 15706 Santiago de Compostela, Spain.
}

\begin{abstract}
SUMMARY: Marine eutrophication caused by an excess supply of nutrients is a serious problem in many coastal areas throughout the world. In the present study we used the capacity of macroalgae (Ulva and Enteromorpha) to integrate the nutrient regime of a water body in order to examine the trophic categorization in the embayments studied. We found that the trophic categorization established based on nutrient levels in macroalgae differed from that established based on concentrations in the water. The waters of the innermost areas of the inlets were the most nutrient enriched; the algae appeared to be more affected by specific local conditions and did not display the gradient of decreasing nutrient concentrations from inner to outer areas that was observed in the water samples. The lack of correspondence between nutrients in the water and in the algae in the present study may have been due to the heterogeneous nutrient conditions found in coastal areas, so that the intertidal algae did not adequately reflect the nutrient levels of the inner zones of the embayments under study.
\end{abstract}

Key words: Enteromorpha, Ulva, eutrophication, nutrients, Rias Baixas, Spain.

RESUMEN: SECTORIZACIÓN TRÓFICA EN LAS RÍAS BAIXAS (NW ESPAÑA): NUTRIENTES EN AGUA Y EN MACROALGAS. - La eutrofización marina, originada por un excesivo aporte de nutrientes, está considerada actualmente como un grave problema en numerosas áreas costeras de todo el mundo. En este estudio empleamos la capacidad de las macroalgas (Ulva y Enteromorpha) de integrar el régimen nutritivo de un cuerpo de agua para realizar una sectorización trófica de las bahías estudiadas. Los resultados de la sectorización trófica en función de las macroalgas fueron diferentes a la establecida en función de las concentraciones de nutrientes en agua. Las zonas más internas de las rías fueron las más enriquecidas en cuanto a nutrientes en agua, pareciendo estar las algas más afectadas por condiciones locales específicas, éstas no siguen el gradiente de concentración del interior al exterior que se observaba en el agua. La falta de correspondencia entre los nutrientes en agua y algas en este estudio puede ser debido a la gran heterogeneidad en las condiciones nutritivas que encontramos en áreas costeras, de forma que las muestras de algas intermareales no hayan reflejado adecuadamente los niveles de nutrientes del interior de las masas de agua estudiadas.

Palabras clave: Enteromorpha, Ulva, eutrofización, nutrientes, Rías Baixas, España.

\section{INTRODUCTION}

Marine coastal eutrophication has been recognised as an emerging problem (Nixon, 1990, 1995; Smetacek et al., 1991; Goldberg, 1995; Wu, 1999), on a worldwide scale (Morand and Briand, 1996). It is mainly caused by an increase in nitrogen and

*Received January 1, 2005. Accepted June 6, 2005. phosphorus availability in littoral ecosystems (Carpenter et al., 1998). This enrichment of nutrients causes proliferation of phytoplankton and opportunistic macroalgae such as Ulva, Enteromorpha, Chaetomorpha and Cladophora (Raven and Taylor, 2003; Curiel et al., 2004), which leads to the disappearance of perennial macroalgae (Duarte, 1995; Pedersen, 1995), and seagrasses (Duarte, 1995; Harlin, 1995; Short and Burdick, 
1996; Short and Wyllie-Echeverria, 1996), thereby affecting associated animal communities. The disappearance of seagrasses often causes remobilization of underlying sediments previously fixed by the plants' roots, producing greater turbidity in the water (Walker and McComb, 1992). Eutrophication leads to changes in macrozoobenthic communities (Everett, 1994; Pihl et al., 1995; Prena, 1995; Neira and Rackemann, 1996; Norkko and Bonsdorff, 1996; Rybarczyk et al., 1996), and fish communities (Rosenberg, 1985; Hansson and Rudstam, 1990; Pihl et al., 1995). In certain coastal areas, eutrophication is also a serious problem for the tourist sector (Rosenberg, 1985; Piriou and Ménesguen, 1992; Morand and Briand, 1996).

Several authors have postulated the idea of using the concentrations of nutrients in macroalgae as indicators of their availability in the environment, instead of traditional water analyses (Ho, 1987; Wheeler and Björnsater, 1992; Fong et al., 1994, 1998; Lyngby and Mortensen, 1994; Horrocks et al., 1995; Lyngby et al., 1999). The levels of nutrients in coastal waters are highly variable. Transient peaks of nutrients caused by sewage effluents, rainwater, etc., are common in these areas, and are difficult to detect by periodic water analysis; even if they are identified, it is difficult to determine their effect on primary production. Macroalgae integrate the nutrient regime over a certain time period and therefore may be suitable for evaluating the trophic conditions of the areas from which they are collected with less sampling effort than with other traditionally used methods.

The main aim of the present study was to use the capacity of macroalgae to integrate the nutrient regime of a water body in order to carry out trophic categorization of the study area, based on the nutrient levels in intertidal samples of two genera of macroalgae (Ulva and Enteromorpha) which proliferate in eutrophic areas. We also compared the results of this method of categorization with those of categorization based on the nutrient levels in water found in a more intensive survey carried out in inner areas of the embayments under study.

\section{MATERIALS AND METHODS}

\section{Sampling}

The study was carried out in four coastal embayments known collectively as the Rías Baixas
(Galicia, NW Spain). The positive estuarine circulation, which concentrates nutrients (Fraga and Margalef, 1979), along with the periodic upwelling events that take place in spring and summer (Álvarez-Salgado et al., 1993), combine to make these embayments very productive systems (Tenore et al., 1982; Prego, 2002).

Samples of macroalgae were collected from intertidal areas at low tide. Most of the fronds were tentatively identified as Ulva rigida and Enteromorpha intestinalis. However, we decided not to identify the algae to species level because of the complications involved in the taxonomy of these genera, in which polymorphism is common (Provasoli and Pintner, 1980). Malta et al. (1999) have shown that Ulva specimens are often assigned to different species when they are in fact different morphotypes of one species. Recently, Hayden et al. (2003) suggested that Ulva and Enteromorpha should not be recognized as separate genera (see also www.algaebase.org).

Algal samples were collected monthly from 22 sampling sites (Fig. 1) between March 1994 and February 1995. Sampling of Enteromorpha was interrupted in September 1994 because the alga had stopped growing at many sites. At each sampling site we collected at least 75 fronds of Ulva and samples from at least 30 mats of Enteromorpha along a transect of $100 \mathrm{~m}$ parallel to the coast. At five selected sites (A2, A8, P2, P5 and V4) fortnightly sampling was carried out between April and November 1994. Algae were stored in mesh bags and transported at $4^{\circ} \mathrm{C}$ to the laboratory.

The data on nutrient concentrations in water were provided by the "Centro de Control da Calidade do Medio Mariño', run under the auspices of the Galician autonomous government (Xunta de Galicia). The water sampling sites are shown in Figure 1. Sampling was carried out weekly at 3 depths $(0-5,5-10,10-15 \mathrm{~m})$. The data used here are means of these 3 values, and can be considered as representative of the surface water layer of the rías (Âlvarez-Salgado et al., 1996).

\section{Chemical analyses}

In the laboratory, algae were washed carefully with distilled water, dried at $50 \pm 1^{\circ} \mathrm{C}$ until constant weight, crushed using a mortar and pestle and stored in plastic bags.

The values of the levels of tissue nitrogen were measured with a LECO CHN 1000 elemental 


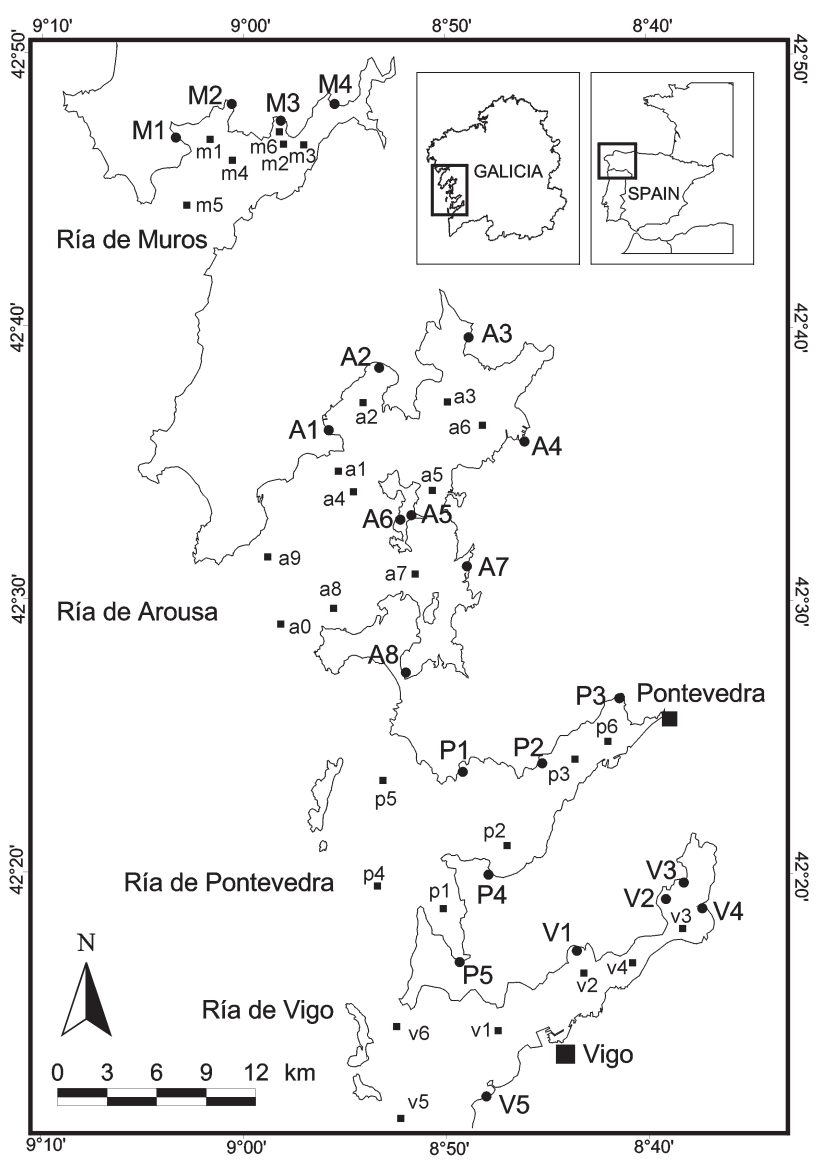

FIG. 1. - Location of sampling sites. Macroalgal sampling sites are indicated by capital letters. Water sampling sites (of the "Centro de Control da Calidade do Medio Mariño"'Xunta de Galicia) are indicated with lower case letters.

analyser, using EDTA as a standard. For phosphorus analysis, samples were combusted in a muffle furnace at $550 \pm 5^{\circ} \mathrm{C}$ for 3 hours and then digested in 2.5 $\mathrm{ml}$ of $2 \mathrm{~N} \mathrm{HCl}$ on a hot plate at $200 \pm 2^{\circ} \mathrm{C}$ for $15 \mathrm{~min}-$ utes. The extracts were filtered using acid washed filters and the samples then made up to $50 \mathrm{ml}$ with distilled water (Chapman and Pratt, 1981). Phosphate in the extracts was determined using the vanadomolybdophosphoric acid colorimetric method, which is the most suitable for the range of concentrations involved here (APHA, AWWA, WEF, 1995). Certified reference plant material, BCR (Community Bureau of Reference) $n^{\circ} 129$ (hay powder), was analysed along with the samples to test the efficiency of the method.

\section{Statistical analysis}

Prior to analysis of variance (ANOVA), water samples were balanced (by making $\mathrm{n}$ equal in the different groups) to make the test more robust.
When there was a missing value for a compound, all of the values corresponding to that compound were omitted for that week of sampling and for all sampling points in the same embayment. The loss of information caused by this procedure was negligible as there were very few missing values relative to the total number of data corresponding to nutrients in the water. The normality of the distribution was tested for each group by the Kolmogorov-Smirnov test, Lilliefors test and by examining frequency histograms. The homogeneity of the variances was verified using Levene's test. Mathematical transformation of data was carried out where necessary to obtain a normal distribution and homogeneous variances. Samples were considered significantly different at $\mathrm{p}<0.05$. Where significant differences were detected by ANOVA, the Tukey-HSD (honestly significant difference) test was applied to establish homogeneous groups (Zar, 1984; Day and Quinn, 1989; Sokal and Rohlf, 1995).

Cluster analyses were carried out by the average linkage between groups method, which uses the information from all pairs of distances by applying the squared Euclidean distance, the most commonly used measure of distance. To avoid variables with high figures having greater emphasis in the final result, data were standardized by transforming them to $\mathrm{z}$ scores by subtracting the mean value from each individual value and dividing it by the standard deviation corresponding to the entire set of values.

\section{RESULTS AND DISCUSSION}

\section{Temporal variations in nutrients}

The changes in monthly mean concentrations of nutrients in the water and in the algae are shown in Fig. 2. Comparison of the contribution of each of the $\mathrm{N}$ compounds to the total dissolved inorganic $\mathrm{N}$, reveals that nitrates comprised the main form of inorganic nitrogen, particularly in winter. There were two peaks in ammonium levels, one in June, when the mean levels were almost equal to those of nitrates, and another higher one in November. The two maximal values were probably associated with the initial stage of decomposition of the organic nitrogen; in the study area there are usually two peaks in primary production, at the end of spring and at the end of summer (Nogueira et al., 1997; Villares and Carballeira, 2003). Nitrites and nitrates followed similar patterns with minimum values in summer and maximum val- 

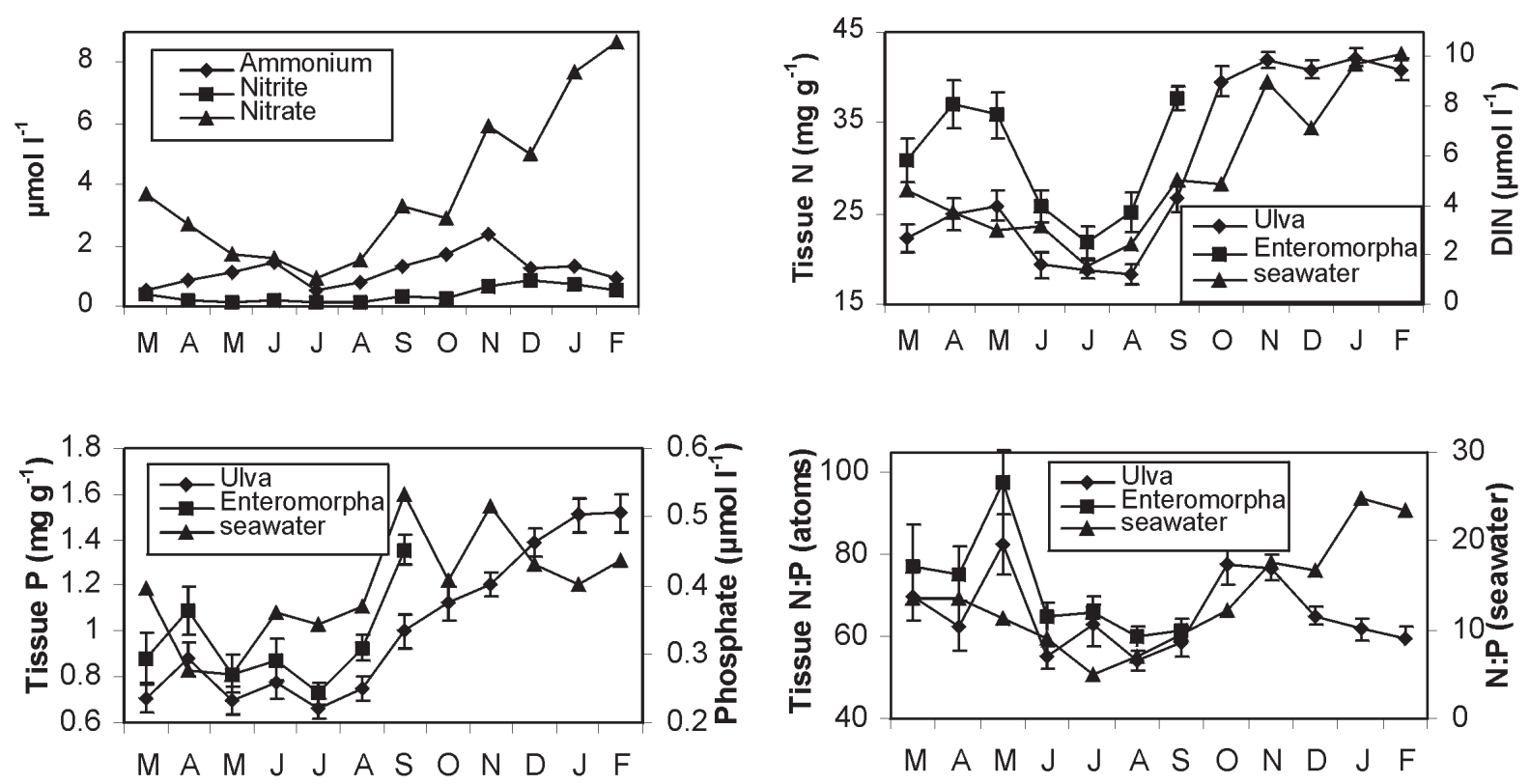

FIG. 2. - Temporal changes in the nutrient concentrations in the water and in macroalgae. Values are monthly means from all the sampling sites. Error bars represent the standard error, these are not shown for nutrients in the water because in most cases they were not large enough to be distinguished from the symbol (triangle).

ues in winter, although the highest concentration of nitrite was found in December and nitrate levels continued to rise until February. In general, phosphate levels did not show as clear a seasonal trend as the $\mathrm{N}$ compounds; lowest mean values were found in spring and summer, and highest values in autumn and winter. The N:P ratio was lower than the Redfield ratio $(\mathrm{N}: \mathrm{P}=16)$ from March to October, and higher in autumn and winter.

The increase in nutrients in the water in winter may have been due to an increase in fluvial inputs and a decrease in primary production, although the peaks in $\mathrm{N}$ compounds appeared to correspond to the degradation of organic matter synthesized in summer, with an ammonium peak in November, followed by peaks of nitrite and nitrate in December and February respectively. Similar results were obtained by Nogueira et al. (1997) for the Ría de Vigo.

Tissue levels of $\mathrm{N}$ followed a similar pattern in both algae: they were lowest in summer, slightly higher in spring and highest in winter. Tissue $\mathrm{P}$ also followed a similar pattern in both Ulva and Enteromorpha, the lowest tissue levels of this nutrient were found in spring and summer then increased gradually throughout autumn and winter. There were two peaks in the $\mathrm{N}: \mathrm{P}$ ratio in algae, in May and in October-November, and minimum values were observed in summer. Temporal changes in tissue nutrients were similar to those reported in most other studies of this type, with high concentrations in winter and low concentrations in summer (Pedersen and Borum, 1996; Malta and Verschuure, 1997; De Casabianca and Posada, 1998; Lyngby et al., 1999).

There was a parallel variation in inorganic nutrients in the water and tissue nutrients in Ulva, which was reflected in the good correlations between them (Table 1). For Enteromorpha the correlations were not as high, and were only significant with nitrates and dissolved inorganic nitrogen (DIN). The nutri-

TABLE 1. - Spearman's correlation coefficients and levels of significance between monthly arithmetic means for nutrients in water and in macroalgae. $\mathrm{n}=12$ for Ulva, $\mathrm{n}=7$ for Enteromorpha. $*$ Significant at $\mathrm{p}<0.05, * *$ Significant at $\mathrm{p}<0.01, * * *$ Significant at $\mathrm{p}<0.001, \mathrm{n} . \mathrm{s} .=$ not significant.

\begin{tabular}{|c|c|c|c|c|c|c|}
\hline & Ammonium & Nitrite & Nitrate & DIN & Phosphate & $\mathrm{N}: \mathrm{P}$ \\
\hline N Ulva & $0.587 *$ & $0.811^{* *}$ & $0.888 * * *$ & $0.916 * * *$ & & \\
\hline $\mathrm{N}$ Enteromorpha & 0.536 n.s. & 0.607 n.s. & $0.786^{*}$ & $0.821 *$ & & \\
\hline P Ulva & & & & & $0.713 * *$ & \\
\hline P Enteromorpha & & & & & 0.536 n.s. & \\
\hline $\mathrm{N}: \mathrm{P}$ Ulva & & & & & & 0.231 n.s. \\
\hline $\mathrm{N}: \mathrm{P}$ Enteromorpha & & & & & & 0.607 n.s. \\
\hline
\end{tabular}


TABLE 2. - One way ANOVA of the concentrations of nutrients in the water for each ría. The degrees of freedom are shown in brackets. Prepared using data provided by the 'Centro de Control da Calidade do Medio Mariño' (Xunta de Galicia). * - Significant at $p<0.05$, ** - Significant at $\mathrm{p}<0.01, * * *$ - Significant at $\mathrm{p}<0.001, \mathrm{n} . \mathrm{s} .=$ not significant.

\begin{tabular}{|c|c|c|c|c|c|}
\hline & & Muros & Arousa & Pontevedra & Vigo \\
\hline Ammonium & $\mathrm{F}$ & $2.701 * \quad(5,270)$ & $5.940 * * * \quad(9,430)$ & $6.326 * * *(5,264)$ & $19.47 * * * \quad(5,300)$ \\
\hline Nitrite & $\mathrm{F}$ & 0.500 n.s. $\quad(5,276)$ & 0.903 n.s. $(9,460)$ & 2.193 n.s. $(5,264)$ & $6.776 * * * \quad(5,300)$ \\
\hline Nitrate & $\mathrm{F}$ & 1.944 n.s. $(5,270)$ & 0.546 n.s. $(9,450)$ & 0.536 n.s. $(5,246)$ & 1.688 n.s. $(5,294)$ \\
\hline DIN & $\mathrm{F}$ & $2.315^{*} \quad(5,264)$ & 1.359 n.s. $(9,430)$ & $2.275^{*} \quad(5,228)$ & $7.249 * * * \quad(5,294)$ \\
\hline Phosphate & $\mathrm{F}$ & $3.538^{* *} \quad(5,276)$ & $8.649 * * * \quad(9,460)$ & $10.64 * * * \quad(5,282)$ & $41.30 * * * \quad(5,300)$ \\
\hline $\mathrm{N}: \mathrm{P}$ & $\mathrm{F}$ & 0.606 n.s. $(5,264)$ & 0.298 n.s. $(9,430)$ & 0.339 n.s. $(5,228)$ & 0.923 n.s. (5.294) \\
\hline
\end{tabular}

ent levels in the water were thus apparently better reflected by Ulva than by Enteromorpha, with the additional advantage that the former is present throughout the entire year.

\section{Trophic categorization in the rías}

The data on nutrients in the water was analysed using a one-way ANOVA to find if there were sig- nificant differences between the sampling sites within each ría (Table 2). Where this occurred homogeneous groups were established using the TukeyHSD multiple comparisons test (Table 3). There were no significant differences for nitrate or $\mathrm{N}: \mathrm{P}$ in any of the rías, in contrast to the findings for ammonium and phosphate. The groups established for the innermost part of the rías always represented the most nutrient enriched areas (Table 3). In the other

TABLE 3. - Groups established using the Tukey-HSD multiple comparisons test for nutrients in the water in each ría. The sites are ordered by increasing the mean concentration of the corresponding nutrient. Sampling sites with the same grouping number were not significantly different. In cases where no groups appear, no significant differences were found. Prepared using data provided by the 'Centro de Control da Calidade do Medio Mariño’ (Xunta de Galicia).

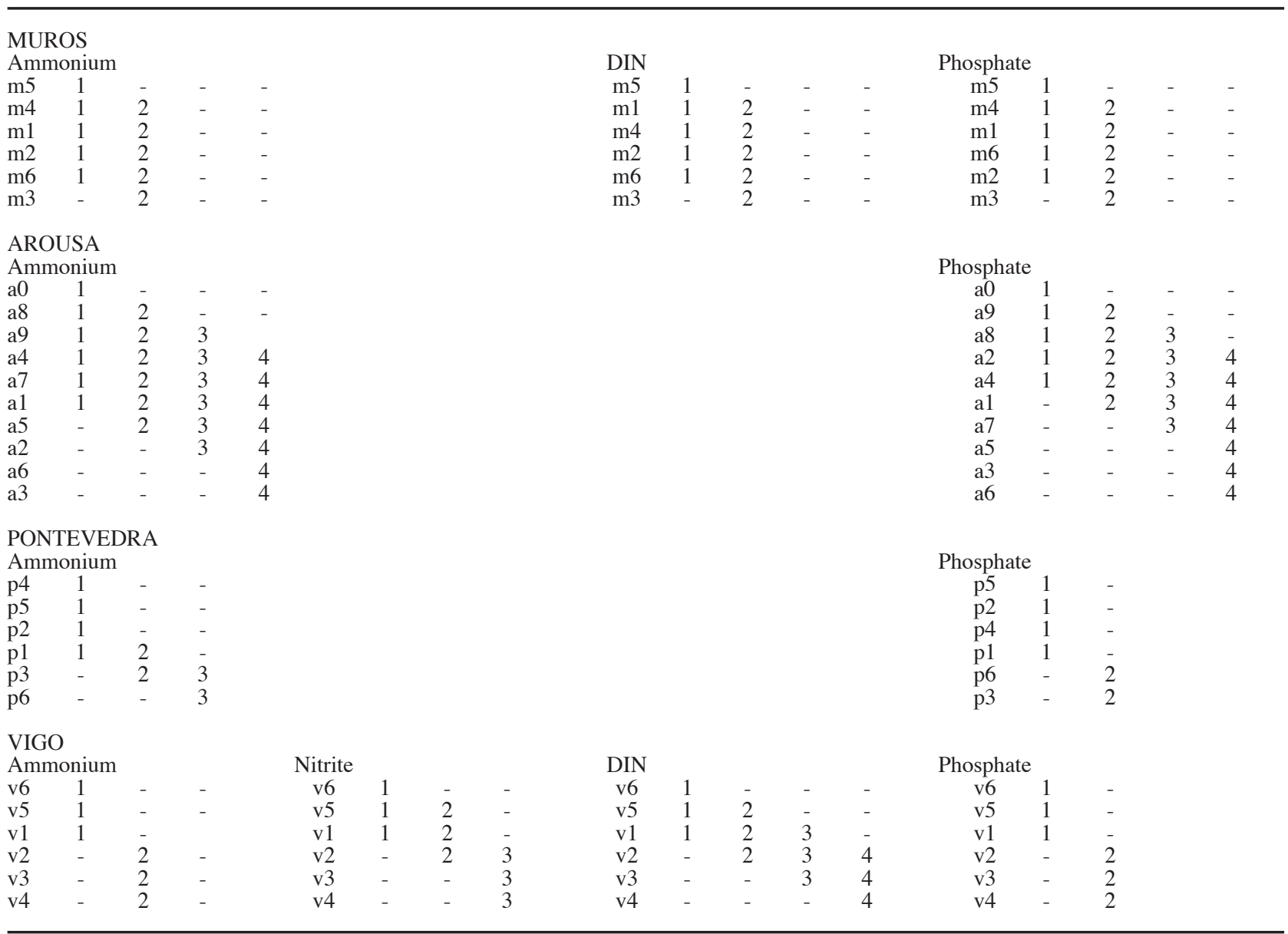




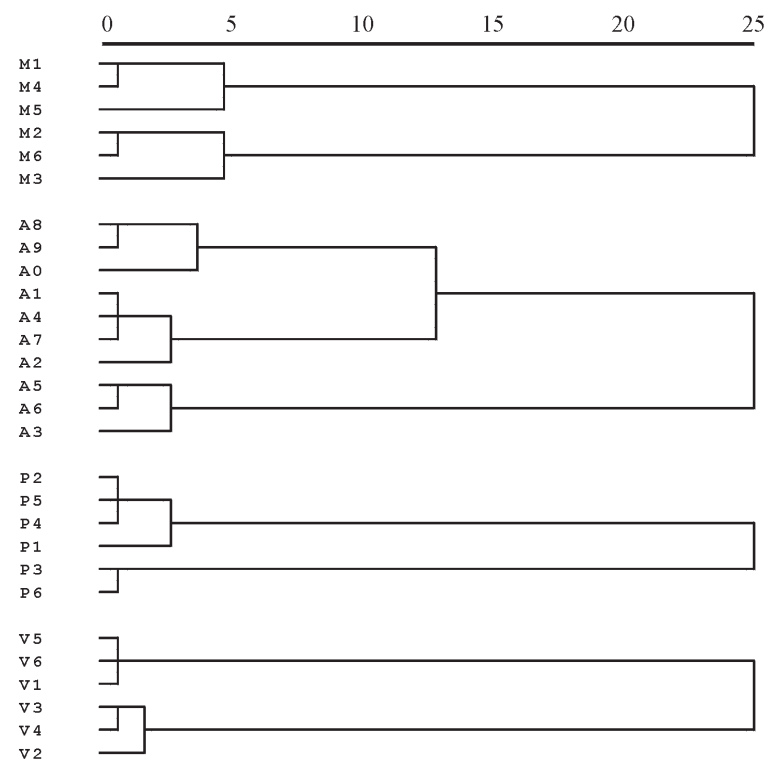

FIG. 3. - Dendrogram of the ría by ría cluster analysis of the mean concentrations for each site, of nitrite, nitrate, ammonium and phosphate. The average linkage between groups method was used with the squared Euclidean distance. Scale in relative units.

groups, the nutrient concentration in the water decreased towards the mouth of the ría. This was to be expected as the innermost part of the ría is the most heavily influenced by nutrient inputs due to the upwelling events which generally occur in the central and inner zones of the rías (Otto, 1975; Tenore and González, 1975; Prego and Fraga, 1992), and also because of fluvial inputs.

Cluster analysis was used to examine the mean levels of nitrite, nitrate, ammonium and phosphate at each sampling site with the aim of detecting homogeneous groups. The dendrogram (Fig. 3) shows a clear distinction between two groups in the rías of Muros, Pontevedra and Vigo, with the inner group always being the most nutrient-enriched. In the outer group in the Ría de Arousa another two subgroups can be distinguished, with the group corresponding to the sites closest to the open sea being the poorest in nutrients. Cluster analysis was also carried out considering phosphate and DIN, i.e.
TABLE 5. - Groups established for nutrients in Ulva and Enteromorpha for each ría, using the Tukey-HSD multiple comparisons test. The sites are ordered by increasing mean concentration of the corresponding nutrient. Sampling sites with the same grouping number were not significantly different. In cases where no groups appear, no significant differences were found.

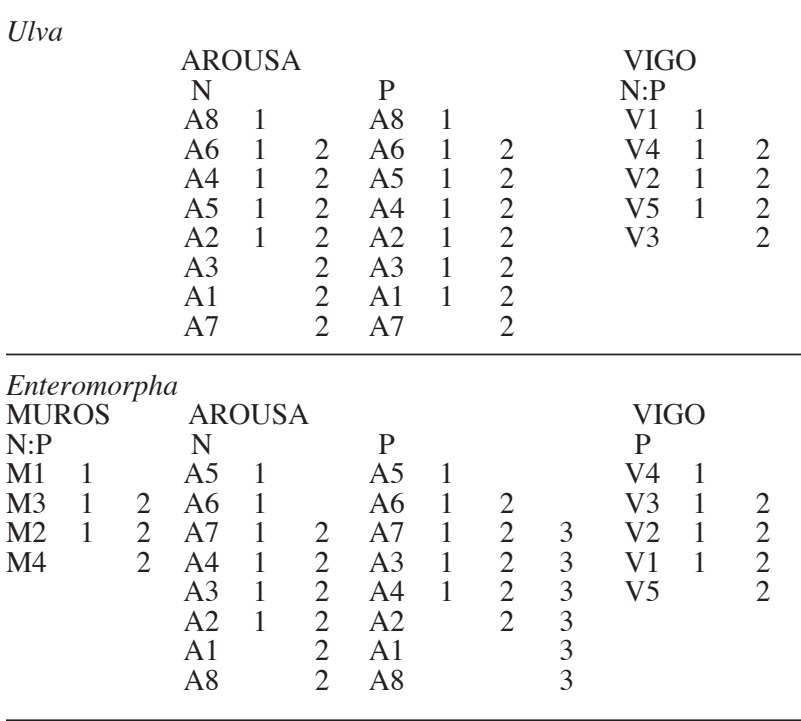

nitrite+nitrate+ammonium, thus avoiding $\mathrm{N}$ compounds having greater emphasis. The results were almost identical to the previous ones.

Trophic categorization in the rías was also carried out with algal data, using the same procedure as before. For Ulva, significant differences in levels of $\mathrm{N}$ and $\mathrm{P}$ in the Ría de Arousa and in the N:P ratio in the rías of Pontevedra and Vigo were detected by one-way ANOVA (Table 4); the groups separated using the Tukey-HSD test are shown in Table 5. For Enteromorpha, significant differences in concentrations of $\mathrm{N}$ and $\mathrm{P}$ at different sites in the Ría de Arousa, in the levels of P in the Ría de Vigo and $\mathrm{N}: \mathrm{P}$ in the Ría de Muros were detected by one way ANOVA. Cluster analysis was also used to group the sites according to the levels of $\mathrm{N}$ and $\mathrm{P}$ in Ulva and Enteromorpha (Fig. 4). The categorization based on algal data differed from that based on water data. The groups established for algae did not follow a gradient from the inner to the

TABle 4. - One way ANOVA for the concentrations of N, P and N:P in Ulva and Enteromorpha of each ría. The degrees of freedom are shown in brackets. $*$ - Significant at $\mathrm{p}<0.05, * *$ - Significant at $\mathrm{p}<0.01, * * *$ - Significant at $\mathrm{p}<0.001$, n.s. $=$ not significant.

\begin{tabular}{|c|c|c|c|c|c|}
\hline & & Muros & Arousa & Pontevedra & Vigo \\
\hline Ulva $\mathrm{N}$ & $\mathrm{F}$ & 0.451 n.s. $(3,28)$ & $2.746^{*} \quad(7,72)$ & 0.401 n.s. $(4,40)$ & 0.742 n.s. $(4,50)$ \\
\hline Ulva $\mathrm{N}: \mathrm{P}$ & $\mathrm{F}$ & 0.537 n.s. $(3,28)$ & 1.232 n.s. $(7,72)$ & $3.599 * \quad(4,40)$ & $4.275 * * \quad(4,50)$ \\
\hline Enteromorpha $\mathrm{N}$ & $\mathrm{F}$ & 1.624 n.s. $(3,20)$ & $3.984 * * \quad(7,24)$ & 1.098 n.s. $(4,25)$ & 1.412 n.s. $(4,20)$ \\
\hline Enteromorpha $\mathrm{P}$ & $\mathrm{F}$ & 2.463 n.s. $(3,20)$ & $6.847 * * * \quad(7,24)$ & 0.715 n.s. $(4,25)$ & $4.246^{*} \quad(4,20)$ \\
\hline Enteromorpha $\mathrm{N}: \mathrm{P}$ & $\mathrm{F}$ & $3.332 * \quad(3,20)$ & 0.221 n.s. $(7,24)$ & 1.544 n.s. $(4,25)$ & 1.051 n.s. $(4,20)$ \\
\hline
\end{tabular}



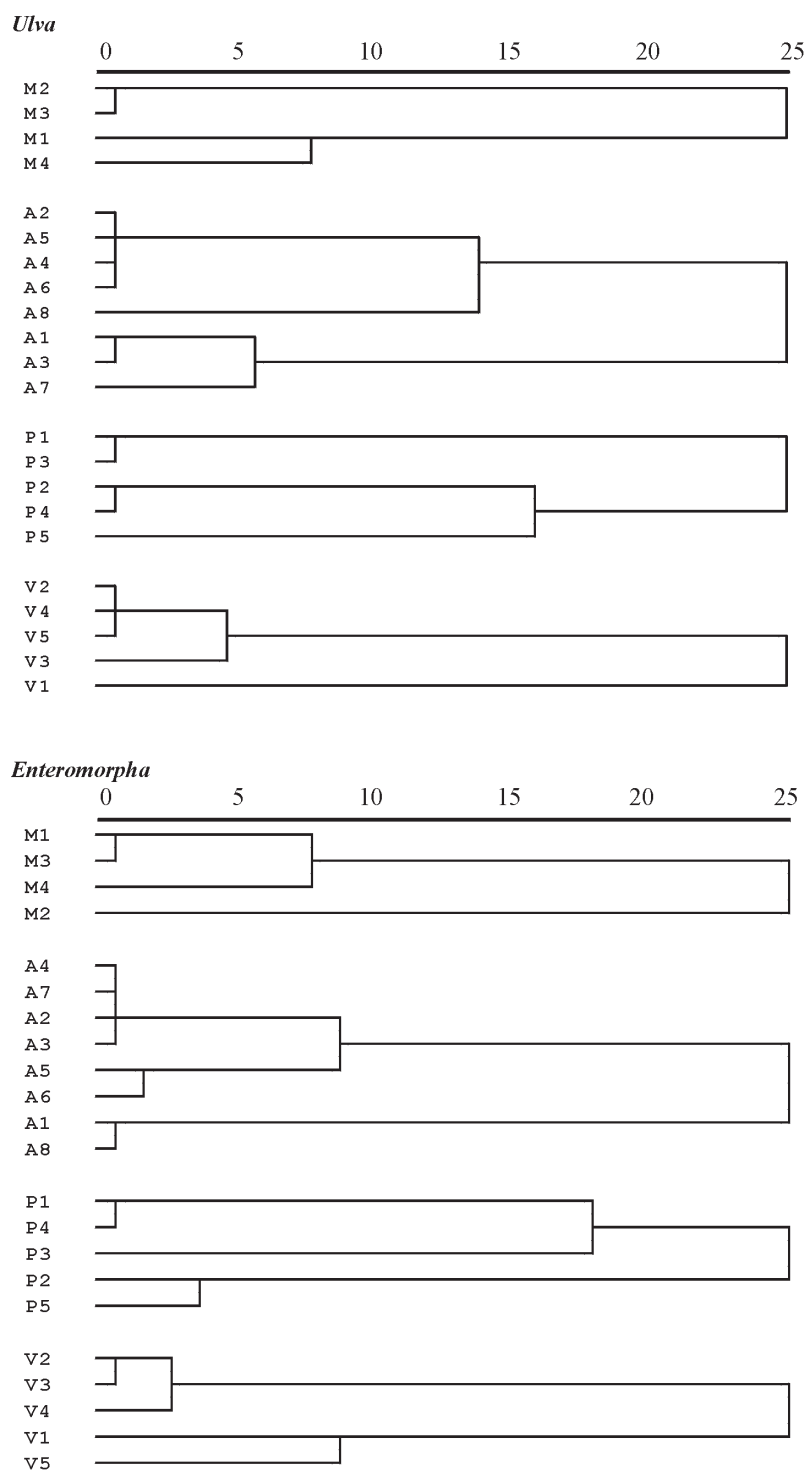

FIG. 4. - Dendrogram of ría by ría cluster analysis of the mean concentrations of N and P in Ulva and in Enteromorpha. The average linkage between groups method was used with the squared Euclidean distance. Scale in relative units.

outer areas of the rías as did the gradients established using the water samples.

One possible explanation for this mismatch between nutrients in the water and in macroalgae may be that the different physiological conditions of the algae throughout the year may affect their use as indicators of the nutrient status of water. At certain times of year, macroalgae may take up nutrients from the water and use them directly for growth without accumulating them. According to Fong et al. (1994), a relationship between nutrients in the water and in macroalgae will only be found when nutrients are not limiting, and can thus be accumulated. Fong et al. (1998) pointed out the usefulness of Enteromorpha intestinalis as an indicator of nutrient enrichment in coastal waters, although they suggested that this indicator would possibly only be accurate when nutrient supplies were high.

The mean concentrations of nutrients in the water cannot be considered low in relation to those reported in other studies that demonstrate the usefulness of macroalgae as indicators of the nutrient status of the water in which they are found (Ho, 1987; Lyngby and Mortensen, 1994; Horrocks et al., 1995; Lyngby et al., 1999). Despite this, the previous approach involving using ANOVA, post-hoc analysis and cluster analysis was repeated for Ulva, although only considering those months in which the concentrations in the samples were higher than the critical tissue concentrations of $\mathrm{N}$ and $\mathrm{P}$. The critical concentration represents the minimum concentration of a nutrient in plant tissue that is needed to support maximum growth rates. Villares and Carballeira (2004) calculated the critical concentrations of tissue $\mathrm{N}$ and $\mathrm{P}$ for Ulva in the study region (24.5 $\mathrm{mg} \mathrm{g}^{-1}$ and $0.810 \mathrm{mg} \mathrm{g}^{-1}$ respectively); the critical concentrations for Enteromorpha in the cited study could not be calculated. Only those algae in which the nutrient levels already allow maximal growth were therefore taken into account, which according to Fong et al. (1994) are the most suitable for reflecting the nutrient status of the water. The eliminated samples corresponded above all to the summer months, and to a lesser extent, to spring. The samples corresponding to the same periods of time for each nutrient in the water in each ría were also omitted. The new classification in terms of nutrients in the water was similar to the original classification, i.e. with decreasing concentrations always from the inner to the outer area of each ría. The classification based on the nutrients in Ulva did not vary much from that observed previously with the annual data, and thus differed from that of the water. In conclusion, the different physiological conditions that may be found in Ulva throughout the year do not appear to explain, at least totally, the different results for water and algae; perhaps using annual average values minimized any interference associated with the seasonal changes in algal physiology. Ho (1987) found highly significant correlations between the mean annual concentrations (calculated from monthly data) of nutrients in the water and in Ulva lactuca.

In general, the sampling points with the highest levels of nutrients in algae were those situated close to small villages (the areas close to large cities were 
discounted when the sampling points where selected). The nutrients originating from these villages may have caused an increase in the nutrient levels in the water, although only locally, thereby affecting the nutrient levels in our algal samples but not the mean levels in the water in the rias.

The N:P ratio in the algae studied may be considered high (median values of 65:1 for Ulva and 68:1 for Enteromorpha, both atomic ratios) in comparison with the values corresponding to the water (median 12:1). Macroalgae usually show values higher than the Redfield ratio (Duarte, 1992), although the present values are higher than the average value reported by this author for seaweeds (49:1). Villares and Carballeira (2003) suggested the retention of $\mathrm{P}$ by sediment as a possible explanation for the low levels of this nutrient in intertidal algae in the study area. It is thus possible that in the intertidal zone, where sediments may have greater importance in the nutrient cycles due to the high ratio between the surface area of sediment and the volume of water, the sequestration of phosphates from the water by sediments would make the local levels of $\mathrm{P}$ in the water relatively low.

In conclusion, it is possible that the local levels of nutrients in the water at the algal sampling points were different from those found at the water sampling points. It appears that because of the high heterogeneity in the levels of nutrients in coastal waters, intertidal macroalgae may not be suitable for indicating the nutrient status of large water bodies.

\section{CONCLUSIONS}

In general, the highest values of both tissue nutrient concentrations and dissolved inorganic nutrients were found in winter and the lowest values found in summer; a situation that may be considered normal at intermediate latitudes. The monthly mean levels of nutrients in Ulva followed a seasonal pattern that apparently reflected the nutrient levels in the water better than the pattern corresponding to Enteromorpha.

The categorization based on the nutrient levels in the water always showed that the inner areas of the rías were the most nutrient enriched; this can be explained by fluvial inputs and upwelling events, which are particularly relevant in this zone. The categorization based on algal data differed from that based on water data. The most enriched sectors, based on algal tissue nutrients, were generally those close to small villages. Even small supplies of nutrients of terrestrial origin may cause, on a local scale, large variability in the trophic conditions in the area immediately adjacent to the coast, which together with the importance of sediment in the nutrient cycles in the shallowest zones may imply great heterogeneity in the nutrient conditions in the study area. Intertidal algae may perhaps adequately reflect local nutrient conditions, but they may not be representative of the nutrient status of large water bodies, as in the case of the embayments under study.

\section{ACKNOWLEDGEMENTS}

We thank the "Centro de Control da Calidade do Medio Mariño" (Xunta de Galicia), in particular Joaquín Mariño and Juan Maneiro, for supplying us with data on nutrients in water. We also thank Xoán Puente for his help with the fieldwork. The authors are grateful for the constructive criticisms of two anonymous referees, which helped to improve the original version of the manuscript.

This study was partly financed by the "Banco de Especímenes Ambientales de Galicia (BEAG)" (Consellería de Medio Ambiente, Xunta de Galicia).

\section{REFERENCES}

Álvarez-Salgado, X.A., G. Rosón, F.F. Pérez, and Y. Pazos. 1993. Hydrographic variability off the Rías Baixas (NW Spain) during the upwelling season. J. Geophys. Res., 98 (C8): 1444714455 .

Álvarez-Salgado, X.A., G. Rosón,, F.F. Pérez, F.G. Figueiras and Y. Pazos. - 1996. Nitrogen cycling in an estuarine upwelling system, the Ría de Arousa (NW Spain). I. Short-time-scale patterns of hydrodynamic and biogeochemical circulation. Mar. Ecol. Prog. Ser., 135: 259-273.

APHA, AWWA, WEF. - 1995. Standard Methods for the Examination of Water and Wastewater. $19^{\text {th }}$ ed., Baltimore.

Carpenter, S.R., N.F. Caraco, D.L. Correll, R.W. Howarth, A. Sharpley and S.V. Smith. - 1998. Nonpoint pollution of surface waters with phosphorus and nitrogen. Ecol. Appl., 8: 559-568.

Chapman, H.D. and P.F. Pratt. - 1981. Métodos de Análisis para Suelos, Plantas y Aguas. Editorial Trillas, Mexico.

Curiel, D., A. Rismondo, G. Bellemo and M. Marzocchi. - 2004. Macroalgal biomass and species variations in the Lagoon of Venice (Northern Adriatic Sea, Italy): 1981-1988. Sci. Mar. 68(1): 57-67.

Day, R.W. and G.P. Quinn. - 1989. Comparisons of treatments after an analysis of variance in ecology. Ecol. Monogr., 59: 433-463.

De Casabianca, M.-L. and F. Posada. - 1998. Effect of environmental parameters on the growth of Ulva rigida (Thau Lagoon, France). Bot. Mar., 41: 157-165.

Duarte, C.M. - 1992. Nutrient concentration of aquatic plants: patterns across species. Limnol. Oceanogr., 37(4): 882-889.

Duarte, C.M. - 1995. Submerged aquatic vegetation in relation to different nutrient regimes. Ophelia, 41: 87-112.

Everett, R.A. - 1994. Macroalgae in marine soft-sediment communities: effects on benthic faunal assemblages. J. Exp. Mar. Biol. Ecol., 175: 253-274.

Fong, P., R.M. Donohoe and J.B. Zedler. - 1994. Nutrient concen- 
tration in tissue of the macroalga Enteromorpha as a function of nutrient history: an experimental evaluation using field microcosms. Mar. Ecol. Prog. Ser., 106: 273-281.

Fong, P., K.E. Boyer and J.B. Zedler. - 1998. Developing an indicator of nutrient enrichment in coastal estuaries and lagoons using tissue nitrogen content of the opportunistic alga, Enteromorpha intestinalis (L. Link). J. Exp. Mar. Biol. Ecol., 231: 63-79.

Fraga, F. and R. Margalef. - 1979. Las rías gallegas. In: Estudio y Explotación del Mar en Galicia, pp. 101-121. Universidad de Santiago de Compostela, Santiago de Compostela.

Goldberg, E.D. - 1995. Emerging problems in the coastal zone for the twenty-first century. Mar. Pollut. Bull., 31: 152-158.

Hansson, S. and L.G. Rudstam. - 1990. Eutrophication and Baltic fish communities. Ambio, 19: 123-125.

Harlin, N. M. - 1995. Changes in major plant groups following nutrient enrichment. In A.J. McComb (ed.), Eutrophic Shallow Estuaries and Lagoons, pp. 173-187. CRC Press, Boca Raton.

Hayden, H.S., J. Blomster, C.A. Maggs, P.C. Silva, M.J. Stanhope and J.R. Waaland. - 2003. Linnaeus was right all along: Ulva and Enteromorpha are not distinct genera. Eur. J. Phycol., 38: 277-294.

Ho, Y.B. - 1987. Ulva lactuca (Chlorophyta, Ulvales) in HongKong intertidal waters - Its nitrogen and phosphorus contents and its use as a bioindicator of eutrophication. Asian Mar. Biol., 4: 97-102.

Horrocks, J.L., G.R. Stewart and W.C. Dennison. - 1995. Tissue nutrient content of Gracilaria spp. (Rhodophyta) and water quality along an estuarine gradient. Mar. Freshwater Res., 46: 975-83.

Lyngby, J.E. and S.M. Mortensen. - 1994. Assessment of nutrient availability and limitation using macroalgae. J. Aquat. Ecosyst. Health, 3: 27-34.

Lyngby, J.E., S. Mortensen and N. Ahrensberg. - 1999 Bioassessment techniques for monitoring of eutrophication and nutrient limitation in coastal ecosystems. Mar. Pollut. Bull., 39: 212-223

Malta, E.-J. and J.M. Verschuure. - 1997. Effects of environmental variables on between-year variation of Ulva growth and biomass in a eutrophic brackish lake. J. Sea Res., 38: 71-84.

Malta, E.-J., S.G.A. Draisma and P. Kamermans. - 1999. Freefloating Ulva in the southwest Netherlands: species or morphotypes? A morphological, molecular and ecological comparison. Eur. J. Phycol., 34: 443-454.

Morand, P. and X. Briand. - 1996. Excessive growth of macroalgae: a symptom of environmental disturbance. Bot. Mar., 39: 491-596.

Neira, C. and M. Rackemann. - 1996. Black spots produced by buried macroalgae in intertidal sandy sediments of the Wadden sea: effects on the meiobenthos. J. Sea Res., 36: 153-170.

Nixon, S.W. - 1990. Marine eutrophication: a growing international problem. Ambio, 19: 101.

Nixon, S. W. - 1995. Coastal marine eutrophication: a definition, social causes, and future concerns. Ophelia, 41: 199-219.

Nogueira, E., F.F. Pérez and A.F. Ríos. - 1997. Seasonal patterns and long-term trends in an estuarine upwelling ecosystem (Ría de Vigo, NW Spain). Estuar. Coast. Shelf Sci., 44: 285-300.

Norkko, A. and E. Bonsdorff. - 1996. Rapid zoobenthic community responses to accumulations of drifting algae. Mar. Ecol. Prog. Ser., 131: 143-157.

Otto, L. - 1975. Oceanography of the Ría de Arosa (NW Spain), Koninklijk Ned. Meteoro. Inst. Mededelingen en Verhandelingen 96, $210 \mathrm{pp}$.

Pedersen, M.F. - 1995. Nitrogen limitation of photosynthesis and growth: comparison across aquatic plant communities in a Danish estuary (Roskilde Fjord). Ophelia, 41: 261-272.

Pedersen, M.F. and J. Borum. - 1996. Nutrient control of algal growth in estuarine waters. Nutrient limitation and the importance of nitrogen requirements and nitrogen storage among phytoplankton and species of macroalgae. Mar. Ecol. Prog. Ser., 142: 261-272.

Pihl, L., I. Isaksson, H. Wennhage and P.-O. Moksnes. - 1995.
Recent increase of filamentous algae in shallow Swedish bays: effects on the community structure of epibenthic fauna and fish. Neth. J. Aquat. Ecol., 29: 349-358.

Piriou, J. Y. and A. Ménesguen. - 1992. Environmental factors controlling the Ulva sp. blooms in Brittany (France). In: G. Colombo, I. Ferrari, V.U. Ceccherelli and R. Rossi. (eds.) Marine Eutrophication and Population Dynamics, pp. 111-115. Olsen and Olsen, Fredensborg, Denmark.

Prego, R. and F.A. Fraga. - 1992. A simple model to calculate the residual flows in a Spanish Ria. Hydrographic consequences in the ria of Vigo. Estuar. Coast. Shelf Sci., 34: 603-615.

Prego, R. - 2002. Nitrogen fluxes and budget seasonality in the Ria de Vigo (NW Iberian Peninsula). Hydrobiologia, 475/472: 161-171.

Prena, J. - 1995. Effects of eutophication on macrobenthos zonation in Wismar Bay (Western Baltic Sea), Arch. Hydrobiol., 133: 245-257.

Provasoli, L. and I.J. Pintner. - 1980. Bacteria induced polymorphism in an axenic laboratory strain of Ulva lactuca (Chlorophyceae). J. Phycol., 16: 196-201.

Raven, J.A. and R. Taylor. - 2003. Macroalgal growth in nutrientenriched estuaries: a biogeochemical and evolutionary perspective. Water Air Soil Poll., 3: 7-26.

Rosenberg, R. - 1985. Eutrophication - the future marine coastal nuisance? Mar. Pollut. Bull., 16: 227-231.

Rybarczyk, H., B. Elkaim, J.G. Wilson and N. Loquet. - 1996. L'eutrophisation en Baie de Somme: mortalités des peuplements benthiques par anoxie. Oceanol. Acta, 19: 131-140.

Short, F.T. and D.M. Burdick. - 1996. Quantifying eelgrass habitat loss in relation to housing development and nitrogen loading in Waquoit Bay, Massachusetts. Estuaries, 19: 730-739.

Short, F.T. and S. Wyllie-Echevarria. - 1996. Natural and humaninduced disturbance of seagrasses. Environ. Conserv., 23: 17-27.

Smetacek, V., U. Bathmann, E.M. Nöthig and R. Scharek. - 1991. Coastal eutrophication: Causes and consequences. In: R.F.C. Mantoura, J.M. Martin and R. Wollast (eds.), Ocean Margin Processes in Global Change, pp. 251-278. John Wiley and Sons Ltd., Chichester.

Sokal, R.R. and F.J. Rohlf. - 1995. Biometry: the principles and practice of statistics in biological research. $3^{\text {rd }}$ Edition, W.H. Freeman and Company, New York.

Tenore, K.R. and N. González. - 1975. Food chain patterns in the Ria de Arosa, Spain: an area of intense mussel aquaculture. In: G. Persoone and E. Jaspers (eds.), Proceedings of the 10th European Symposium of Marine Biology, pp. 601-619. Ostend, Belgium.

Tenore, K.R, L.F. Boyer, R. M. Cal, J. Corral, C. García-Fernández, N. González, E. González-Gurriaran, R.B. Hanson, J. Iglesias, M. Krom, E. López-Jamar, J. McClain, M.M. Pamatmat, A Pérez, D.C. Rhoads, G. De Santiago, J. Tietjen, J. Westrich and H.L. Windom. - 1982. Coastal upwelling in the Rias Bajas, NW Spain: Contrasting the benthic regimes of the Rias de Arousa and Muros. J. Mar. Res., 40: 701-772.

Villares, R. and A. Carballeira. - 2003. Seasonal variation in the concentrations of nutrients in two green macroalgae and nutrient levels in sediments in the Rías Baixas (NW Spain). Estuar. Coast. Shelf Sci., 58: 887-900.

Villares, R. and A. Carballeira. - 2004. Nutrient limitation in macroalgae (Ulva and Enteromorpha) from the Rías Baixas (NW Spain). Mar. Ecol.- P.S.Z.N., 25(3): 225-243.

Walker, D.I. and A.J. McComb. - 1992. Seagrass degradation in Australian coastal waters, Mar. Pollut. Bull., 25: 191-195.

Wheeler, P.A. and B.R. Björnsäter. - 1992. Seasonal fluctuations in tissue nitrogen, phosphorus and N:P for five macroalgal species common to the Pacific northwest coast. J. Phycol., 28: 1-6.

$\mathrm{Wu}$, R.S.S. - 1999. Eutrophication, water borne pathogens and xenobiotic compounds: environmental risks and challenges. Mar. Pollut. Bull., 39: 11-12.

Zar, J.H. - 1984. Biostatistical Analysis. Second edition, Prentice Hall, Englewood Cliffs, New Jersey.

Scient. ed.: C. Heip 
